\title{
Papillary Carcinoma Thyroid presenting as Right Ventricular Outflow Tract Obstruction - A Case Report and Review of Literature
}

\author{
Dr. Mintu Mathew Abraham ${ }^{1 *}$, Dr. Lakshmi Haridas $\mathrm{K}^{1}$, Dr. Sindhu Nair $\mathrm{P}^{2}$, Dr. VM Pradeep ${ }^{3}$
}

\author{
${ }^{1}$ Department of Medical Oncology, Regional Cancer Centre Trivandrum, Medical College Kumarapuram Rd, Medical College Campus, Chalakkuzhi, \\ Thiruvananthapuram, Kerala 695011, India \\ ${ }^{2}$ Department of Pathology, Regional Cancer Centre Trivandrum, Medical College Kumarapuram Rd, Medical College Campus, Chalakkuzhi, \\ Thiruvananthapuram, Kerala 695011, India \\ ${ }^{3}$ Department of Nuclear Medicine, Regional Cancer Centre Trivandrum, Medical College Kumarapuram Rd, Medical College Campus, Chalakkuzhi, \\ Thiruvananthapuram, Kerala 695011, India
}

DOI: $10.36347 /$ sjmcr.2021.v09i02.017 $\quad$ | Received: 26.12.2020 | Accepted: 11.01 .2021 | Published: 27.02 .2021

*Corresponding author: Dr. Mintu Mathew Abraham

Abstract

Cardiac metastasis from thyroid malignancy is a rare phenomenon, with an incidence of $2 \%$. The metastatic presentation can be simultaneous or subsequent to the diagnosis of primary thyroid malignancy. Even when cardiac tissue has inherent properties to escape tumor seeding, among carcinoma thyroid, follicular and anaplastic subtypes are the most vulnerable for cardiac metastases. Papillary carcinoma thyroid very rarely produce cardiac metastases per se and cardiac chamber involvement is even more a rarity. Only 11 such cases of papillary carcinoma thyroid with cardiac chamber metastases have been reported in the literature. We present here a compilation of these cases along with ours. Our patient presented de-novo with right ventricular mass and outflow tract obstruction. Excision of the mass showed metastatic carcinoma thyroid and subsequently, completion thyroidectomy showed carcinoma thyroid. He received radioiodine ablation postoperatively and is clinically well at 10 months of initial presentation.

Keywords: Cardiac metastasis, Papillary thyroid carcinoma, Ventricular mass, RVOT obstruction.

Copyright $(\mathcal{O} 2021$ The Author(s): This is an open-access article distributed under the terms of the Creative Commons Attribution 4.0 International License (CC BY-NC 4.0) which permits unrestricted use, distribution, and reproduction in any medium for non-commercial use provided the original author and source are credited.

\section{INTRODUCTION}

Metastatic involvement of heart occurs infrequently and the sites of primary in descending order of commonness are lung, lymphoma, breast, leukemia, stomach, melanoma, liver and colon [1]. Cardiac metastasis (CM) from thyroid malignancy is seen in $2 \%$ of patients. The largest published series on $\mathrm{CM}$ from thyroid carcinoma was by Catford et al., in which the commonest histologic subtypes were follicular and anaplastic among 54 patients, reported over 130 year period ${ }^{2}$. Lymphatic dissemination is the usual dictum in papillary carcinoma thyroid (PTC). To the contrary, we report here a patient with right ventricular outflow tract obstruction (RVOT) prospectively diagnosed as PTC.

\section{CASE RePORT}

A 62-year-old male, former-smoker, sought medical advice for complaints of diplopia, headache and exertional palpitations lasting for the past 6 months. The patient denied any chest pain, orthopnoea, paroxysmal nocturnal dyspnoea, syncope on exertion or bowel angina. He is a known hypertensive on oral medications. He reported no family history of cancer or personal history of cerebrovascular accident/transient ischemic attack. The past surgical history was remarkable for partial thyroidectomy done 18 years back, whose details were not followed up or unavailable. The primary physician noticed changes in electrocardiogram and referred the patient to higher centre for further management.

At presentation, there was clubbing and grade 1 pedal oedema. He was maintaining sinus rhythm with 75 beats per minute and a respiratory rate of 18 per minute. Blood pressure was normal and there was no carotid bruit. Cardiovascular examination was remarkable for pan systolic murmur in the lower left sternal border. Central nervous examination was within normal limits. Chest X-ray showed dilated superior vena cava with cardiothoracic ratio of 0.45 ; ECG showed sinus rhythm of 75 per minute, $90^{\circ}$ axis, q in III $\mathrm{aVF}$, incomplete RBBB, with QRS duration of $100 \mathrm{~ms}$ and $\mathrm{T}$ inversion $\mathrm{V} 1-\mathrm{V} 6$.

On detailed Echocardiogram (Echo), ejection fraction was $61 \%$ and there was a $23 \times 28 \mathrm{~mm}$ mass in the right ventricle attached to the inter-atrial septum 
causing severe right ventricular outflow tract (RVOT) obstruction $(86 / 35 \mathrm{~mm} \mathrm{Hg})$ and right ventricular hypertrophy. The left ventricular function was normal. The routine blood values including complete blood counts, biochemistry and coagulation profile were within normal limits.

The patient underwent sternotomy after confirming the cardiac findings on preoperative transesophageal Echo. Per operatively a $3 \times 3 \mathrm{~cm}$ fleshy, broad based mass was seen arising from the outlet septum protruding into and obstructing the RVOT. The mass was seen extending into the interventricular septum as well. The tricuspid valve was normal. Maximal excision of the mass was done. Post-operative period was uneventful and Echo at discharge showed good biventricular function with no residual mass in the right ventricle.

Grossly, the excised greyish white masses measured $3.5 \times 2 \times 2 \mathrm{~cm}$. Histopathological examination showed a neoplasm which contained atypical cuboidal cells with moderate cytoplasm, enlarged vesicular nuclei with fine chromatin predominantly in sheets and in follicular pattern as well (Fig-1a). The nuclei showed intranuclear grooves and occasional follicles contained thick colloid. A thin rim of vascular tissue with attached cardiac muscle bundles was seen at the periphery. The atypical tumour cells tested diffusely positive for TTF1 (Fig-1b). The patient entertained the diagnosis of metastatic papillary carcinoma thyroid (follicular variant) to right ventricle. On further workup, residual thyroid tissue concentrated Technetium99 (Fig-1c). Further, completion thyroidectomy done at local hospital showed carcinoma thyroid and he underwent radioiodine ablation for residual thyroid uptake. Currently, the patient is clinically well at 10 months of initial presentation.

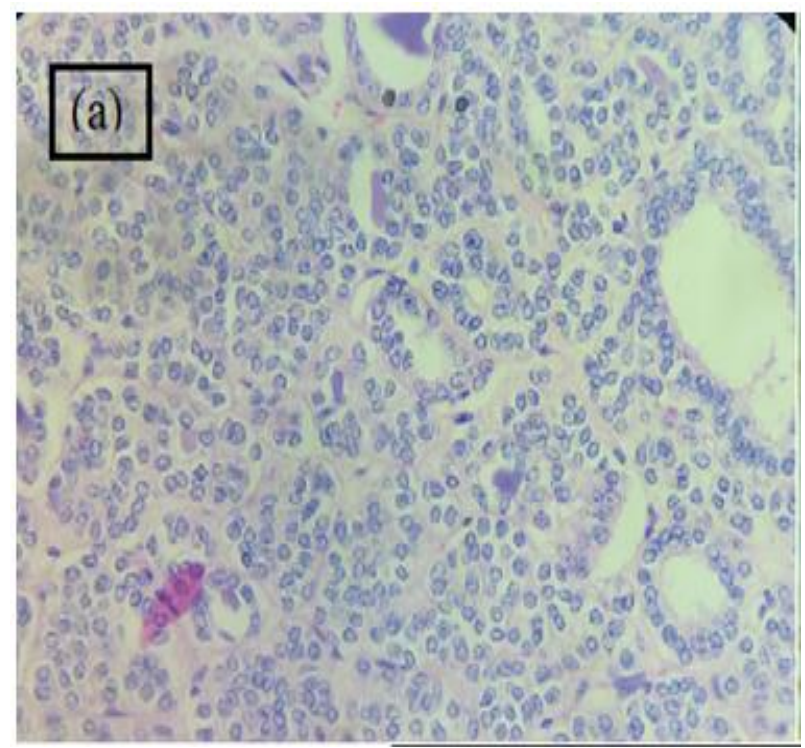

Fig 1(a): Microscopy (H\&E 400x) of excised ventricular mass showing tumour cells with enlarged vesicular nuclei in sheets and follicular pattern

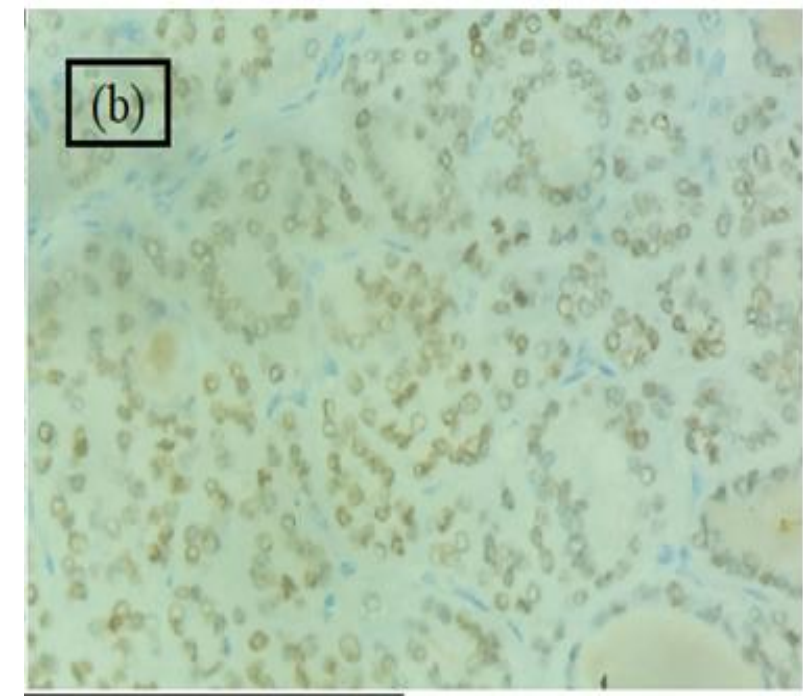

Fig-1(b): Immunohistochemical staining (400x) of excised ventricular mass showing diffuse nuclear positivity for TTF1

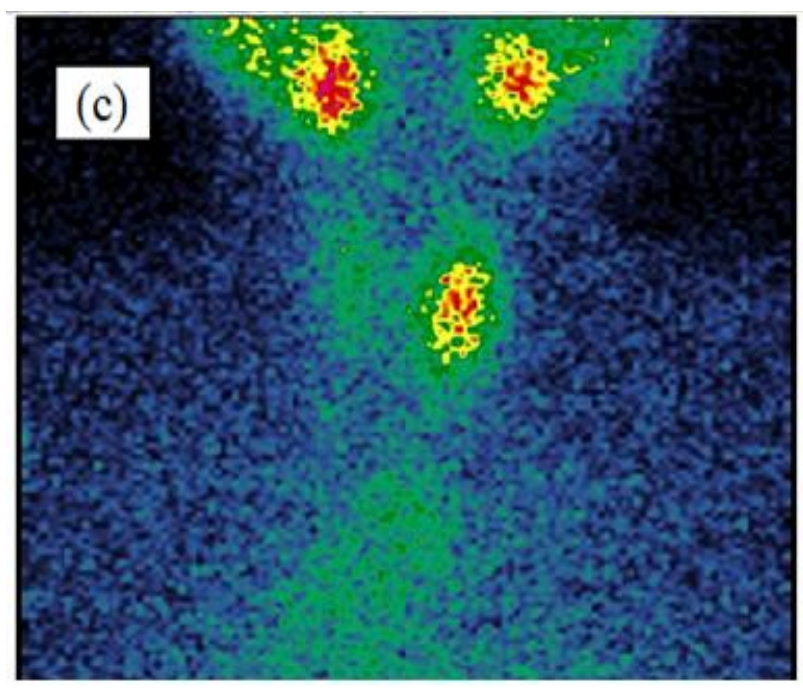

Fig-1(c): Tc99 scan showing concentration in residual thyroid

\section{DiscuSSION}

Follicular and anaplastic carcinoma thyroid are well established to throw hematogenic metastases. However, PTC very rarely spreads hematogenously and involves the cardiac tissue. We present here a rare case of PTC with cardiac chamber involvement. Only 11 such cases have been reported in the literature, which are summarised in Table-1 [1-8].

CM may be silent (necropsy finding) or
oppressive (cardiac rhythm disturbances, atrioventricular blocks, congestive heart failure etc.) in their clinical presentation. They are usually seen as part of disseminated metastases in a patient with established thyroid malignancy, but de-novo presentations also can be seen. Echo findings which suggest malignancy include cardiac mass with or without extension to major vessels, intramural mass and/or pericardial 
involvement. Our patient presented de-novo with RVOT obstruction due to right ventricular mass.

Generally, cardiac tissue is bypassed from tumor seeding by virtue of its low blood supply, high myocardial contractility and rapid coronary blood flow. Even then, CM does occur via hematogenous, lymphogenous or locoregional contiguous extension (intravascular or extravascular) routes [2]. Hematogenous dissemination and local intravascular extension are frequently observed in follicular thyroid carcinoma where there is a tendency towards angioinvasion and venous metastasization. Conversely, PTC tends to invade locally and disseminate by lymphatic vessels of the neck and upper mediastinum. The typical sites for $\mathrm{CM}$ are the pericardium, epicardium and right side of the heart with most of the intracardiac disease presenting with right heart failure, arrhythmias or features of direct invasion [1]. Our patient had follicular variant of PTC, which could have contributed to the hematogenic metastatic potential.

Largely, the CM reported in literature were in patients with other known metastatic sites where it is comparatively easier to entertain a clinical diagnosis of metastasis. In this seam, ancillary investigations including serum thyroglobulin, thyroid function tests and antithyroglobulin can complement the diagnosis. But in cases where prior malignancy confirmation is absent, as in our case, further work up is warranted. In this patient, RVOT obstruction was the first sign of metastatic disease with only a history of partial thyroidectomy 10 years ago. He underwent surgical excision as there were features of RVOT obstruction and raised right ventricular pressure. $\mathrm{He}$ is further planned for completion thyroidectomy as the residual thyroid tissue concentrated Technetium99. PET-CT was deferred. This will be followed by Iodine131 scan and ablation/adjuvant treatment with therapeutic doses of Iodine131 as required.

The management of such CM is highly individualised. The detection at necropsy notifies its indolent behaviour at least in a subset, and hence they may possibly be observed. If the metastasis amount to cardiac decompensation, surgical intervention will help in preventing mortality. Our patient underwent surgical excision of the right ventricular mass, which was therapeutic at that time point and diagnostic for the diagnosis of metastatic carcinoma thyroid as well.

Table-1: Summary of PTC cases with cardiac chamber metastasis reported in literature till date

\begin{tabular}{|c|c|c|c|c|c|c|c|}
\hline $\begin{array}{l}\text { Author / Year of } \\
\text { publication (ref) }\end{array}$ & $\begin{array}{l}\text { Age / } \\
\text { Sex }\end{array}$ & $\begin{array}{l}\text { Symptom } \\
\text { (Duration) }\end{array}$ & $\begin{array}{l}\text { Prior } \\
\text { confirmatio } \\
\text { n of thyroid } \\
\text { malignancy }\end{array}$ & $\begin{array}{l}\text { Cardiac } \\
\text { chamber } \\
\text { involved }\end{array}$ & $\begin{array}{l}\text { Subtype of } \\
\text { thyroid } \\
\text { malignancy }\end{array}$ & $\begin{array}{l}\text { Treatment } \\
\text { received }\end{array}$ & $\begin{array}{l}\text { Survival } \\
\text { as } \\
\text { reported }\end{array}$ \\
\hline Fukuda etal/ $2000^{1}$ & $62 \mathrm{y} / \mathrm{M}$ & $\begin{array}{l}\text { Chest pain, } \\
\text { dyspnea, pretibial } \\
\text { edema }\end{array}$ & Yes & $\mathrm{RV}, \mathrm{LV}$ & PTC & $\begin{array}{l}\text { Medical } \\
\text { management, } \\
\text { biopsy, } \\
\text { Radiotherapy }\end{array}$ & $27 \mathrm{~d}$ \\
\hline $\begin{array}{l}\text { Seiki Hasegawa } \\
\text { etal / } 2002^{2}\end{array}$ & $78 \mathrm{y} / \mathrm{F}$ & $\begin{array}{l}\text { Heart failure, neck } \\
\text { pain }\end{array}$ & No & RA & PTC & Surgery & $36 \mathrm{~d}$ \\
\hline $\begin{array}{l}\text { Kalyan } \\
\text { Thippeswamy } \\
\text { Anand etal / } 2003^{2}\end{array}$ & $33 y / F$ & $\begin{array}{l}\text { Generalised } \\
\text { weakness }\end{array}$ & No & RV & $\begin{array}{l}\text { PTC with } \\
\text { follicular variant }\end{array}$ & Surgical excision & $\begin{array}{l}\text { NED at } 1 \\
\text { yr fu }\end{array}$ \\
\hline $\begin{array}{l}\text { Seiichiro Sugimoto } \\
\text { etal / } 2006^{2}\end{array}$ & $61 \mathrm{y} / \mathrm{M}$ & SVC syndrome & No & RA & $\begin{array}{l}\text { PTC transformed } \\
\text { to ATC }\end{array}$ & Surgery & $12 \mathrm{~d}$ \\
\hline $\begin{array}{l}\text { Sherif E. Moustafa } \\
\text { etal / } 2007^{2}\end{array}$ & $68 \mathrm{y} / \mathrm{M}$ & $\begin{array}{l}\text { Shortness of breath, } \\
4 \text { weeks }\end{array}$ & Yes & RV & PTC & Palliation & 2 weeks \\
\hline $\begin{array}{l}\text { Yuko Yamagami } \\
\text { etal / } 2008^{3}\end{array}$ & $74 \mathrm{y} / \mathrm{M}$ & $\mathrm{NR}$ & No & Atrium & PTC & Surgery & NR \\
\hline $\begin{array}{l}\text { Shailja Kaul etal / } \\
2012^{4}\end{array}$ & $54 \mathrm{y} / \mathrm{F}$ & Nil & Yes & RA & $\begin{array}{l}\text { PTC tall cell } \\
\text { variant }\end{array}$ & Surgery & $\begin{array}{l}\text { Alive at } 2 \\
\text { years }\end{array}$ \\
\hline $\begin{array}{l}\text { Hooman } \\
\text { Yarmohammadi } \\
\text { etal / } 2013^{5}\end{array}$ & $76 \mathrm{y} / \mathrm{M}$ & Abnormal ECG & Yes & LV & PTC & NR & NR \\
\hline $\begin{array}{l}\text { Toshiyuki Ikeoka } \\
\text { etal/ } 2014^{6}\end{array}$ & $66 \mathrm{y} / \mathrm{F}$ & $\begin{array}{l}\text { Acute myocardial } \\
\text { infarction }\end{array}$ & Yes & $\begin{array}{l}\mathrm{LV}, \\
\text { pericardiu } \\
\mathrm{m}\end{array}$ & $\begin{array}{l}\text { PTC with } \\
\text { anaplastic } \\
\text { transformation }\end{array}$ & Palliation & 4 months \\
\hline $\begin{array}{l}\text { Gema Bruixola } \\
\text { etal / } 2014^{7}\end{array}$ & $73 y / F$ & Heart failure & Yes & RA & PTC & Sunitinib & 7 months \\
\hline $\begin{array}{l}\text { Charles K. Lin etal } \\
/ 2015^{8}\end{array}$ & $74 y / F$ & $\begin{array}{l}\text { Exertional dyspnea } \\
\text { and palpitations, } 2 \\
\text { days }\end{array}$ & Yes & RV & PTC & $\begin{array}{l}\text { Permanent } \\
\text { pacemaker }\end{array}$ & Expired \\
\hline Present case & $62 \mathrm{y} / \mathrm{M}$ & $\begin{array}{l}\text { Exertional } \\
\text { palpitations, } 6 \mathrm{~m}\end{array}$ & No & RV & $\begin{array}{l}\text { PTC with } \\
\text { follicular variant }\end{array}$ & Surgical excision & $\begin{array}{l}\text { On } \\
\text { follow up }\end{array}$ \\
\hline
\end{tabular}

Abbreviations: RA - right atrium, RV - right ventricle, LA - left atrium, LV - left ventricle, PTC - papillary thyroid carcinoma, NR not reported. 
Patient consent - obtained.

\section{CONCLUSION}

Thyroid carcinoma has extremely good survival outcome and deserve identification/better understanding of rare metastatic sites. This rare case highlights the surpassed mechanisms of tumor escape/ invasion and thus adds to the literature.

\section{REFERENCES}

1. Fukuda A, Saito T, Imai M, Ishii K, Miwa K. Metastatic cardiac papillary carcinoma originating from the thyroid in both ventricles with a mobile right ventricular pedunculated tumor. Jpn Circ J. 2000;64:890-2. DOI:10.1253/jcj.64.890.

2. Catford SR, Lee KT, Pace MD, Marasco SF, Longano A, Topliss DJ. Cardiac metastasis from thyroid carcinoma. Thyroid. 2011;21:855-66. DOI: 10.1089/thy.2010.0273.

3. Yuko Yamagami, Masayuki Tori, Masayuki Sakaki, Shigeaki Ohtake, Masaaki Nakahara, Kazuyasu Nakao. Thyroid carcinoma with extensive tumor thrombus in the atrium. Gen Thorac and Cardiovasc Surg. 2008; 56:555-8. DOI 10.1007/s11748-008-0307-y.

4. Kaul S, Tulchinsky M, Campbell DB, Crist HS, Manni A. Isolated cardiac metastasis from papillary thyroid cancer: prolonged survival with late diagnosis related to inadequate positron emission tomography preparation. Thyroid. 2012 Apr 1;22(4):443-4.

5. Yarmohammadi H, Tacher V, Faulhaber PF, Gilkeson RC, Aktay R, Kamouh A, Chow CH. Imaging of dedifferentiated papillary thyroid carcinoma with left ventricular metastasis: A rare presentation of papillary thyroid metastatic disease. Journal of cancer research and therapeutics. $2013 \mathrm{Jul}$ 1;9(3):490-492.

6. Ikeoka $\mathrm{T}$, Ito $\mathrm{T}$, Ando $\mathrm{T}$. Left ventricular infiltration from thyroid papillary carcinoma mimicking the electrocardiographic changes of acute myocardial infarction. Endocrine. 2014 Nov 1;47(2):652-653.

7. Bruixola G, Segura Á, Caballero J, Andrés A, Reche E, Escoín C, Díaz-Beveridge R. Heart failure as first sign of development of cardiac metastases in a patient with diagnosis of papillary thyroid carcinoma on treatment with tyrosinekinase inhibitors: differential diagnoses and clinical management. Case reports in oncology. 2014;7(2):591-9.

8. Lin CK, Cochet A, Lewi JE. Complete Heart Block in a Patient With Metastatic Papillary Thyroid Carcinoma. Fed Pract. 2015;32:34-5. PMCID: PMC6363289. PMID: 30766021. 